\title{
Os primeiros filmes de Joaquim Pedro de Andrade: história e linguagem
}

Tatiana Pontes de Oliveira

ARAÚJO, L. C.

Joaquim Pedro de Andrade:

primeiros tempos.

São Paulo: Alameda, 294 p., 2013.

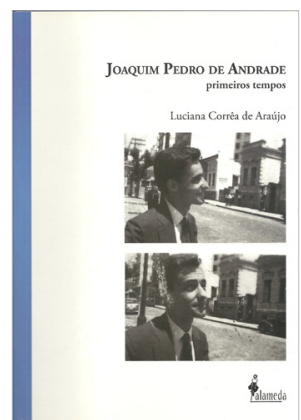

Resumo: Em Joaquim Pedro de Andrade: primeiros tempos são analisados quatro filmes do diretor cinemanovista. A partir de um levantamento histórico, o foco de análise recai sobre o período de formação e os filmes iniciais do cineasta. Destacam-se suas reflexões sobre as relações entre o cinema de ficção e o documentário, e as especificidades da linguagem cinematográfica.

Palavras-chave: Joaquim Pedro de Andrade; cinema; história do cinema.

Abstract: The early films by Joaquim Pedro de Andrade: history and language - Joaquim Pedro de Andrade: primeiros tempos (early days) four films by this "Cinema Novo" director are analyzed. From a historical research, the analysis focus is on this filmmaker's training period and his initial films. His reflections on relations between fiction cinema and documentary, besides the specificities of the cinematographic language are highlighted.

Keywords: Joaquim Pedro de Andrade; cinema; cinema history. 
Joaquim Pedro de Andrade: primeiros tempos é um livro decorrente da tese de doutorado defendida por Luciana Corrêa de Araújo na Escola de Comunicações e Artes da USP. Na obra a autora apresenta o início da trajetória do cineasta, um dos precursores do Cinema Novo e diretor de Macunaíma (1969). Sua intenção é justamente a de tratar da formação de Joaquim Pedro e, para isso, aborda quatro dos seus primeiros filmes: os curtas-metragens $O$ mestre de Apipucos e o poeta do Castelo (1959) e Couro de gato (1961), o documentário Garrincha, alegria do povo (1963) e o longa-metragem de ficção O padre e a moça (1966).

Ao longo de todo o livro, a autora apresenta uma vasta documentação pesquisada durante o desenvolvimento da tese. As informações vindas de entrevistas recentes feitas com a família, amigos ou pessoas que trabalharam com Joaquim Pedro, de arquivos e cartas trocadas entre o diretor e amigos próximos ou de periódicos da época são relacionadas na feitura de uma rica trama que apresenta a partir de vários pontos de vista a obra do cineasta, seu contexto de produção e sua recepção pela crítica.

Nesse sentido, a abordagem do trabalho de Joaquim Pedro é feita num exercício de "escovar a história a contrapelo", como pensado por Benjamin (1994, p. 225), ou seja, a partir do cruzamento de dados pesquisados em fontes muito diversas, a autora consegue criar um panorama que engloba não só a obra cinematográfica, mas as relações com seu processo de criação, os questionamentos do autor diante da sua produção e de seu período histórico.

O primeiro capítulo, denominado "Vontade de fazer filmes", trata da biografia de Joaquim Pedro, contando sobre sua família, sua formação, sua relação com a arte e a literatura. Seus primeiros contatos com o cinema ainda enquanto cursava a faculdade de Física no Rio de Janeiro também são foco de atenção. O cinema se colocava, então, como um desafio, por ser uma linguagem pouco habitual para Joaquim Pedro; já a literatura era, para ele, um terreno bem conhecido, e dessa experiência surge um diálogo entre as duas linguagens, que se estenderá por toda a sua obra.

O livro segue com o estudo dos filmes, a começar por $O$ mestre de Apipucos e o poeta do Castelo, documentário que tinha por objetivo retratar a vida diária, os afazeres cotidianos e o método de trabalho de dois escritores brasileiros, Gilberto Freyre e Manuel Bandeira. Ao analisar o filme, Araújo destaca alguns aspectos que fazem pensar sobre a relação entre o documentário e a ficção. Aponta que Joaquim Pedro se vale das particularidades do cinema e propõe um jogo com espaço para a criação ficcional, principalmente ao trabalhar com uma rigorosa decupagem dos planos para conceber cada um dos personagens.

O terceiro capítulo é dedicado a Couro de gato, curta-metragem que fez parte do filme Cinco vezes favela (1962). A autora define o filme como uma "ficção com acentuado traço documental" e afirma que Joaquim Pedro opera na fronteira entre a ficção e o documentário ao usar no elenco meninos da favela e atores profissionais e voltar 
seu olhar para os excluídos da sociedade. Araújo afirma que o diretor se aproxima mais que nunca do neorrealismo italiano e que, para concretizar seu desejo de expor a realidade nacional, lança sobre ela uma visão crítica elaborada pela razão - a atitude social do artista - e também pelas possibilidades dramáticas do cinema.

O terceiro filme analisado é Garrincha, alegria do povo; Luciana Araújo traz uma discussão sobre o cinema direto e o cinema verdade, uma vez que Joaquim Pedro intencionou fazer o filme aos moldes do cinema direto. Nesse sentido, a autora destaca que o esquema de trabalho empreendido pelo diretor estava aberto à improvisação, pois ele filmou sem roteiro, mas a falta de recursos técnicos adequados e a sofisticada montagem deram ao filme outros desdobramentos.

A voz de Joaquim Pedro é trazida a partir das reflexões do diretor sobre o filme, enquanto Araújo vai costurando sua análise. Chama a atenção para o fato de que Joaquim Pedro, mesmo falando em não interferência na realidade, também tinha clareza sobre as influências do realizador e sobre o processo de seleção da realidade mostrada.

Assim, enquanto o diretor afirma não ter conseguido fazer um filme de cinema direto, o que, segundo ele, pode ser percebido, por exemplo, pelos excessos técnicos - ou "pirotecnia" - e pela imposição da tristeza sobre a alegria da torcida que a tudo resiste, a autora lembra um dos filmes vistos anteriormente e diz que, a despeito das diferenças de época e de referências, tanto o documentário sobre o poeta Manuel quanto o que aborda Manuel, o jogador, tinham a intenção de tratar do que está para além do registro da câmera.

O quinto capítulo fecha o livro com a análise de O padre e a moça, primeiro longametragem de ficção de Joaquim Pedro, que tem como ponto de partida um poema de Carlos Drummond de Andrade. Toda a primeira parte do texto é construída por uma montagem de depoimentos que apresentam o período de produção do filme. Falam o diretor, os atores, a equipe técnica, dando ao leitor informações detalhadas sobre várias faces do filme. Nesses depoimentos está a afirmação de Joaquim Pedro de que trabalhar com ficção significa um abandono de certa onipotência sobre a realidade.

A análise de Araújo toma esses depoimentos como referência e trata do filme em sua amplitude: o roteiro, a fotografia, a montagem, a importância dada à relação espacial já desenvolvida nos trabalhos anteriores, as referências cinematográficas que alimentam a criação do diretor - o processo de "essencialização" buscado por Joaquim Pedro, tendo em vista a obra de Bresson, e o interesse do diretor na corporalidade que já está presente em $O$ padre e a moça e vai se estender para seus filmes realizados a seguir.

A ordem cronológica de análise dos filmes dá ao leitor a possibilidade de perceber a continuidade no processo de criação de Joaquim Pedro, e, desse modo, nota-se que a cada filme as questões problematizadas no trabalho anterior são resgatadas ou superadas. A minuciosa descrição dos aspectos técnicos e da linguagem é usada para análise do modo pelo qual Joaquim Pedro emprega os recursos cinematográficos como meios expressivos. 
Em paralelo, ao analisar as primeiras produções do cineasta, a autora nos dá um rico panorama do surgimento do Cinema Novo, suas preocupações com a arte, com a crítica e com o mercado. Conhecer o contexto da formação inicial de Joaquim Pedro, suas experimentações com a linguagem cinematográfica e seu contexto cultural é muito instigante para que se pense tanto suas obras desenvolvidas posteriormente como a produção cinematográfica na atualidade.

Tatiana Pontes de Oliveira é bacharel em Comunicação Social, fotógrafa e doutoranda em Comunicação e Semiótica na PUC-SP. É professora na graduação em Publicidade e Propaganda e Design Digital do Centro Universitário Senac.

tapontes@gmail.com

\section{Referências}

BENJAMIN, W. Magia e técnica, arte e política: ensaios sobre literatura e história da cultura. São Paulo: Brasiliense, 1994. 